\title{
Eucalyptus transcriptome analysis revealed molecular chaperones highly expressed in xylem
}

\author{
Danieli Gonçalves ${ }^{1 *}$, Jorge Lepikson-Neto², Marcela Salazar², Leandro Nascimento², Eduardo Camargo², \\ Wesley Marques ${ }^{2}$, Gonçalo Pereira', Carlos Ramos ${ }^{1}$ \\ From IUFRO Tree Biotechnology Conference 2011: From Genomes to Integration and Delivery \\ Arraial d'Ajuda, Bahia, Brazil. 26 June - 2 July 2011
}

\section{Background}

Plant development is very plastic, being coupled to environmental cues. As sessile organisms, plants must be able to respond rapidly to environmental stresses such as changes in temperature and salinity, heavy metals and water deficit. Efficient stress response systems are prerequisites for plant survival and productivity [1].

Molecular chaperones (or Heat Shock Proteins - HSP) compose a ubiquitous class of proteins involved in cellular protein quality control (PQC) and homeostasis. They play a critical role in folding and degradation of polypeptides, and therefore, in maintenance and modulation of cellular pathways, which are dependent of function (correct folding) and availability (stability and degradation) of involved proteins, under normal and stress conditions [2].

Genetics and proteomics studies of wood formation have highlighted some chaperones up-regulated in xylem of Eucalyptus, Pinus and Populus species, stating that they may play an important role in cell wall formation and xylem development $[3,4]$.

Different species of Eucalyptus are known for their superior performance in growth, wood quality and resistance to different types of stress [5]. Such characteristics are probably driven by distinct gene expression coordination in xylogenesis. Eucalyptus grandis is one of the most planted species in the world due to its rapid growth, wide adaptability and wood quality. Eucalyptus globulus wood has higher S/G ratio which provides high yields in cellulose extraction [6].

Lignin extraction consumes large quantities of chemicals and energy, and many efforts have been made to

\footnotetext{
*Correspondence: danieligoncalves@yahoo.com.br

'Laboratório de Bioquímica de Proteínas, Dep. de Química Orgânica -

Instituto de Química, Universidade Estadual de Campinas, UNICAMP, Brazil

Full list of author information is available at the end of the article
}

improve this process by modifying lignin content or composition in trees, in order to reduce lignin content or make it easier to extract. Results have been achieved by supplementation and genetic modification $[7,8]$.

This study aims to identify chaperones possibly involved in wood formation and quality of wood for pulp and paper industries.

\section{Methods}

The RNA-Seq reads were produced from two xylem libraries for comparison between species (Eucalyptus globulus andE. grandis), and from two libraries for evaluating flavonoids supplementation (E. urograndis supplemented with naringenin and narigenin-chalcone).

Reads were aligned against the assembled unigenes using SOAP2 aligner [9] configured to allow up two mismatches, discard sequences with "N"s and return all optimal alignments. To perform the differential expression analysis between libraries, a normalization and statistics pipeline were applied using DEG-seq software [10] (confidence rate: 99\%; cut-off: 0.01). RNA-Seq libraries and Gbrowse are available at http://bioinfo03. ibi.unicamp.br/eucalyptus/.

\section{Results and discussion}

In this study, we identified chaperones differentially expressed between Eucalyptus species. RNA-seq analysis revealed chaperones as smHsp, Hsp40, Hsp70, Hsp90 and Hsp100 between 1 and 3 fold up-regulated in xylem of E. globulus (Figure 1).

Eucalyptus urograndis narigenin-chalcone or naringenin supplemented also presented molecular chaperones highly expressed (Figure 2). Recent findings reported that supplementation with these flavonoids can inhibit lignin biosynthesis, and change lignin content and composition [10]. 

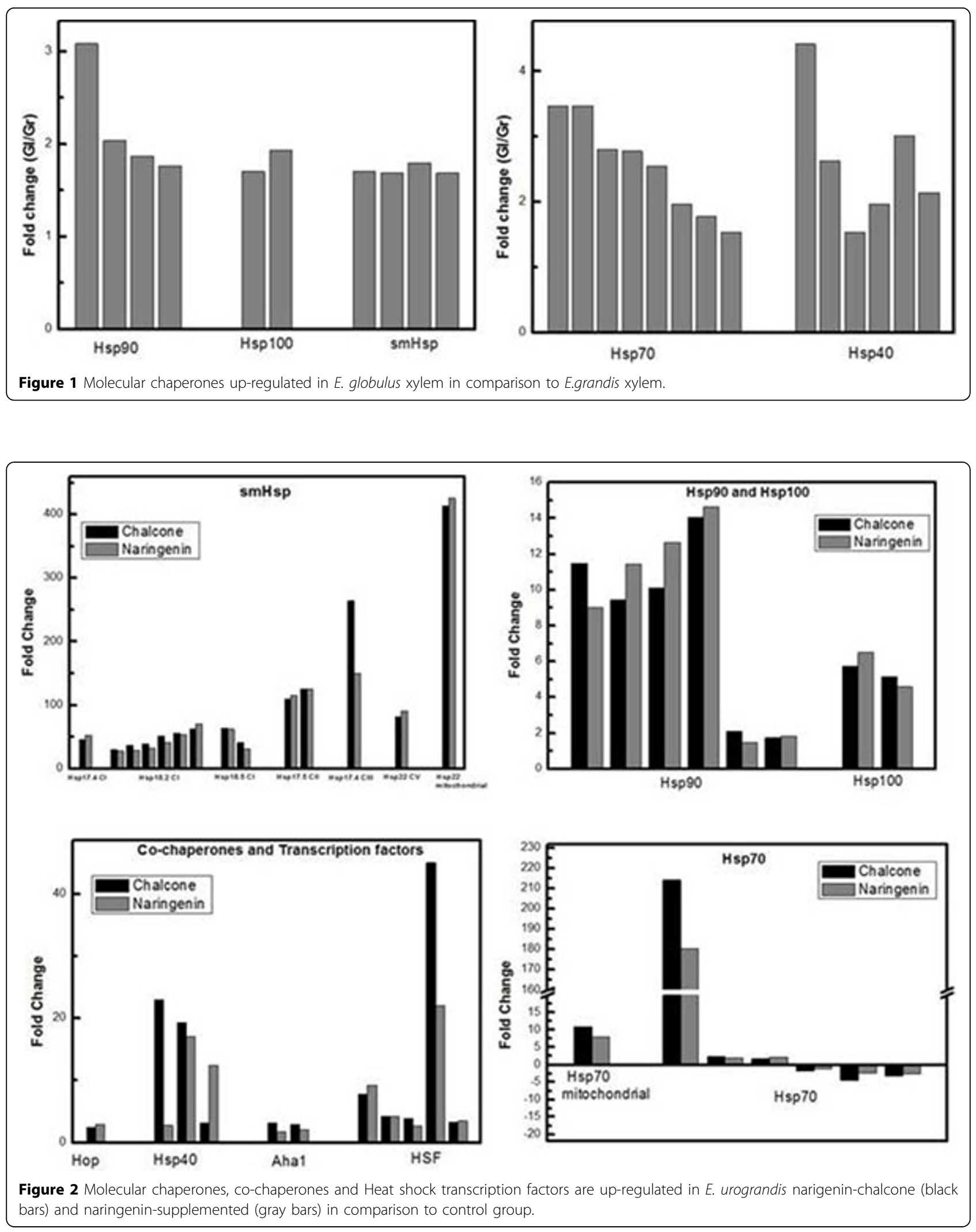
SmHsp family is active in a wide range of environmental stresses, including heat, cold, drought, salinity and oxidative stress [11]. Gion et al [4] noted smHsp accumulation in wood forming tissues, and suggested a role in extending the cell wall thickening phase during xylogenesis.

Hsp70 family acts in protein refolding, translocation, and facilitating the degradation of unstable proteins, directing them to lysosomes or proteasomes [12].

Hsp90 family has a select group of substrate proteins as polymerases and kinases [13]. InA. thaliana some kinases are required for optimal cell elongation, which is important for plant growth and vascular system formation [14].

We have successfully identified chaperones with higher expression on E. globulus xylem and in E. urograndis flavonoids-supplemented plants, which provide evidences to link xylogenesis and chaperone expression. Those findings are crucial on helping to elucidate the role of chaperones on plant development, stress response and wood formation.

\section{Author details}

'Laboratório de Bioquímica de Proteínas, Dep. de Química Orgânica Instituto de Química, Universidade Estadual de Campinas, UNICAMP, Brazil.

2Laboratório de Genômica e Expressão, Dep. de Genética, Evolução e Bioagentes - Instituto de Biologia, Universidade Estadual de Campinas, UNICAMP, Brazil.

Published: 13 September 2011

\section{References}

1. Neumann D, Nover L, Partier R, Scharf KD: Heat shock and other stress response systems of plants. Biol. Zbl 1989, 108:1-156.

2. Tiroli-Cepeda AO, Ramos CHI: An Overview of the Role of Molecular Chaperones in Protein Homeostasis. Protein Pept. Lett 2011, 18(2):101-9.

3. Le Provost G, Paiva J, Pot D, Brach J, Plomion C: Seasonal variation in transcript accumulation in wood forming tissues of maritime pine (Pinus pinaster Ait.) with emphasis on a cell wall Glycine Rich Protein. Planta 2003, 217:820-830

4. Gion JM, Lalanne C, Le Provost G, Ferry-Dumazet H, Paiva J, Chaumeil P, Frigerio JM, Brach J, Barré A, de Daruvar A, Claverol S, Bonneu M Sommerer N, Negroni L, Plomion C: The proteome of maritime pine wood forming tissue. Proteomics 2005, 5:3731-3751.

5. Grattapaglia D, Kirst M: Eucalyptus applied genomics: from gene sequences to breeding tools. New Phytol 2008, 179:911-929.

6. Silva JC: Eucalipto: a madeira do futuro. In Revista da Madeira. Volume 59 Curitiba; 2001:114.

7. Baucher M, Halpin C, Petit-Conil M, Boerjan W: Lignin: genetic engineering and impact on pulping. Crit Rev Biochem Mol Biol 2003, 38:305-350.

8. Chen $W$, Yun M, Deng F, Yogo Y: The rates of maize growth and lignin biosynthesis change after root-applied chalcone. Weed Biology and Management 2005, 5:118-122.

9. Li R, Yu C, Li Y, Lam TW, Yiu SM, Kristiansen K, Wang J: SOAP2: an improved ultrafast tool for short read alignment. Bioinformatics 2009, 25(15):1966-1967.

10. Wang $L$, Feng $Z$, Wang $X$, Wang $X$, Zhang $X$ : DEGseq: an $R$ package for identifying differentially expressed genes from RNA-seq data. Bioinformatics 2010, 26(1):136-138.

11. Vierling E: The roles of heat shock proteins in plants. Annu. Rev. Plant Physiol. Plant Mol. Biol 1991, 42:579-620.

12. Hartl FU: Molecular chaperones in cellular protein folding. Nature 1996, 381:571-580.
13. Gava LM, Ramos CHI: Human 90kDa heat shock protein Hsp90 as a target for cancer therapeutics. 2009, 3:10-21.

14. Guo H, Li L, Ye H, Yu X, Algreen A, Yin Y: Three related receptor-like kinases are required for optimal cell elongation in Arabidopsis thaliana. PNAS 2009, 106(18):7648-7653.

doi:10.1186/1753-6561-5-S7-P109

Cite this article as: Gonçalves et al.: Eucalyptus transcriptome analysis revealed molecular chaperones highly expressed in xylem. BMC Proceedings 2011 5(Suppl 7):P109.

\section{Submit your next manuscript to BioMed Central and take full advantage of:}

- Convenient online submission

- Thorough peer review

- No space constraints or color figure charges

- Immediate publication on acceptance

- Inclusion in PubMed, CAS, Scopus and Google Scholar

- Research which is freely available for redistribution 